\title{
Wall of Body of Uterus
}

National Cancer Institute

\section{Source}

National Cancer Institute. Wall of Body of Uterus. NCI Thesaurus. Code C41270.

Wall of body of uterus is composed of three layers: endometrium, myometrium, and perimetrium. Endometrium is the inner mucosal layer lining and is covered with columnar epithelium and tubular glands. Myometrium is a thick, muscular layer, consisting larg ely of bundles of smooth muscle fibers arranged in long itudinal, circular, and spiral patterns, and interlaced with connective tissue. Perimetrium is the outer layer composed of the peritoneal layer of the broad ligament that covers the body of the uterus and part of the cervix. 